\title{
Tropical Crops and Resilience to Climate Change
}

Noureddine Benkeblia*, Melinda McHenry, Jake Crisp, and Philippe Roudier

Noureddine Benkeblia

Department of Life Sciences / The Biotechnology Centre

The University of the West Indies

Mona campus

Kingston 7

Jamaica

and

Department of Life Sciences / The Biotechnology Centre

The University of the West Indies

Mona campus

Kingston 7

Jamaica

Email: noureddine.benkebia@uwimona.edu.jm

\section{Melinda McHenry}

Geography and Spatial Science; School of Technology, Environments and Design,

University of Tasmania

Sandy Bay, 7001, Tasmania

Australia

Email: melinda.mchenry@utas.edu.au 


\section{Jake Crisp}

Geography and Spatial Science; School of Technology, Environments and Design

University of Tasmania

Newnham, 7250, Australia

Email: jracrisp@utas.edu.au

\section{Philippe Roudier}

\section{CIRED}

Campus du Jardin Tropical

45 bis, avenue de la Belle Gabrielle

94736 Nogent-sur-Marne Cedex

France

Email:roudier@centre-cired.fr

*Correspondence author: noureddine.benkeblia@uwimona.edu.jm 


\section{CONTENT}

1 Introduction

2 Tropical agriculture systems

3 Generalised impacts of climate change on agriculture in the tropics

3.1 Climate variability

3.2 Impacts on soils

3.3 Pests and diseases

3.4 Crop and varietal impacts

4 Vulnerabilities of tropical crops and production systems to climate change

4.1 Vulnerability of tropical crops to climate change

4.2 Impacts and consequences of climate changes on tropical crop production systems

\subsubsection{Climate changes and crop productivity}

4.2.2 Future climate change and crop quality (nutrients)

\subsubsection{Other types of impacts}

5 Adaptation and mitigation measures for curbing negative impacts of climate change on tropical agriculture systems

6 Conclusions and perspectives

\section{References}




\section{$1 \quad$ INTRODUCTION}

It is anticipated that agricultural output will have to increase by $70 \%$ to feed a population of more than 9 billion by the year 2050 (Benkeblia 2012). The capacity of global high-intensity farming systems to continue to guarantee productive returns whilst maintaining system stability will eventually decline, and thus new opportunities for agriculture are being realised in tropical environments. As population growth is greatest in tropical regions, and commensurate with rapid industrialisation and a change in traditional land use practices, it is presumed that equatorial production systems will be some of the most vulnerable to climate change.

The pressure on tropical agricultural systems is two-fold. Firstly, tropical agricultural systems are located primarily in areas of political instability, with high populations vulnerable both to the impacts of climate change itself, and with lesser current organisational or community knowledge to be able to plan and implement sustainable and intensive food production systems. A second challenge depends on the capacity of tropical agricultural land managers and researchers to assess and strengthen the adaptive capacity of food crops to the predicted temperature and carbon dioxide raising which might be above the goal of $2{ }^{\circ} \mathrm{C}$ by the end of this century - which now appears to be a conservative estimate of temperature increase (Challinor et al. 2014).

Temperature and rainfall fluctuations, deficits and efficacy are suitable indicators of climate change as they both reflect a general increase or decrease in climate variables over time (Nwagbara 2008, 2015; Uguru et al. 2011). Typically, tropical regions are characterised by a limited variation in temperature, but a wide variation in rainfall. Therefore, the tropics contain some of the wettest and driest locations on Earth subject to variations in these conditions. Total warming in the tropics is estimated to be about $0.7-0.8^{\circ} \mathrm{C}$. Regions within the tropics such as 
the Sahara, Sahel and Arabian Peninsula have been among the most rapidly warming across the globe.

Tropical agricultural systems are located between the latitudes of $22.5^{\circ}$ North and $22.5^{\circ}$ South (Figure 1). These systems are characterized by high level of solar, relatively high and consistent temperatures through the year, high number of storm systems as cyclones, hurricanes, and thunderstorms, and air pressure distribution producing varying patterns of wind and air-mass movement.

\section{<Insert Figure 1 here>}

According to Köppen (1900a, 1900b), two main agricultural tropical systems fall into this classification. The first are humid tropics (HT) characterized by constantly warmth, and high annual rainfall supporting dense tropical rain forests, while high rainfall and good soil moisture maintain evergreen forests. These systems are well adapted with low soil erosion and good fertility, therefore more adapted to perennial and forest crops. The second are the wet-dry tropics (WDT) with greater variation and contrasting rainfall in specific seasons during the year. some well-suited annual crops, forages, and tree fruits. However, the latter are considered the most fragile and most in need of novel production approaches.

In this chapter, we assess the vulnerability and resilience of tropical agricultural systems to the hypothesised, modelled and actual measured impacts of a changing climate. We examine potential system vulnerabilities associated with soils, biosecurity and crop productivity, highlighting risks and opportunities associated with an increasingly warm, yet variable, climate. 


\section{TROPICAL AGRICULTURE SYSTEMS}

The tropics provide important environmental services and resources and productive lands that are essential to meeting future global food supply (Goldsmith and Cohn 2017). The tropics are also the site of increased commercial agricultural expansion (Laurance et al. 2014).

There is a lack of standardised and widely accepted definitions relating to farming systems which can impose serious limitations on the adaptability of farmers in the face of climate change (Morton, 2007). In this section, we attempt to clarify nomenclature pertaining to agricultural systems by distinguishing between crop production systems (the series of processes involved in the growing of crops ) and the farming system which in turn is an integral part of the broader agro-ecosystem and landscape (FAO 2017). A hierarchical approach to farming systems allows one to consider impacts and opportunities across a broad-spectrum of land management approaches in turn.

Farming systems of the tropics include arable systems, pastoral approaches, mixed approaches, subsistence dependencies, commercial, intensive, extensive, sedentary and nomadic farming (Fig. 2). Primarily, however, tropical farming systems are typically small family holdings (some - semi-commercial, many subsistence farming system), which comprise $85 \%$ of the world's farms (Harvey et al. 2014a) and are actually the backbone of agricultural commodities trading in developing countries (IFPRI 2017).

Traditional farming is characterised by methods such as slash-and-burn agriculture which requires clear-felling and fire techniques to establish a suitable area for crop production. Traditional agriculture simply put adopts farming systems that require the least input, that is, 
it is a farming system that enables farmers to meet the economic demand of feeding the modern world with minimal physical effort. Minimising physical effort sees modern machinery like tractors and harvesters used, as well as chemically engineered herbicides, pesticides and fungicides to conquer soil-borne disease (Bodin 2017).

\section{<Insert Figure 2 here>}

\section{GENERALISED IMPACTS OF CLIMATE CHANGE ON AGRICULTURE IN THE TROPICS}

The vulnerability of tropical crops to climate change is primarily influenced by four factors (1) the changes that will occur in the climate in tropical regions; (2) the capacity of agricultural soils and growing media to continue to provide water, nutrients and stability to agricultural crops; (3) the inherent capacity of the crop or variety to withstand variation in rainfall, nutrients, $\mathrm{CO}_{2}$ and modified management practices; and, (4) the governability and management of farming systems and the adaptive capacity of tropical agricultural communities.

\subsection{Climate variability}

Recent climate simulation exercises grouped in international projects such as CMIP-5 or Cordex and using Global Circulation Models (GCMs) and sometimes Regional Climate Models have provided improved results on the future evolution of climate variables (temperatures, rainfall, wind) at regional and sometimes local scales. However, even if the skill of such models has dramatically improved, there is still - and will always be- uncertainties on future climate change due to (i) differences among climate models (ii) uncertainties on data and (iii) assumptions on future Greenhouse gases (GHG) emissions. This third type of uncertainty is generally taken into account using GHG emission scenarios (like the former 
'SRES' scenarios) or concentration pathways (called RCP and used for the last IPCC report) that represent several potential world futures in terms of emission (Table 1).

\section{<Insert Table 1 here>}

Uncertainty in future climate projections is a very important parameter that should not be forgotten in order to avoid maladaptation. For some regions of the World (Mediterranean area or Southern Africa for example) the models agreement is high for temperature increase and precipitation decrease, even if the magnitude differs among models. For other regions like West Africa, the situation is more challenging, and the climate models project contrasted cumulated rainfall evolution, except for some regions like Senegal where a significant decrease could occur in the future (Sylla et al. 2016). So, in West Africa, it is difficult to conclude whether the cumulated annual rainfall will decrease or not. However, studies like Déqué et al. 2016 project that there would be less rainy days but with more intense rainfall in the future. More intense rainy events are also projected by Sylla et al. (2016) for a pessimistic pathway (RCP8.5). In this region, like in many regions of the world, the future warming is projected to be significant and ranges between $+1{ }^{\circ} \mathrm{C}$ and $+3.2^{\circ} \mathrm{C}$ in 2100 for a medium concentration pathway (RCP4.5). With more pessimistic pathways (RCP8.5) and for some models, the temperature increase could even reach $+6^{\circ} \mathrm{C}$. These climatic changes may have several impacts on cropping systems. Taking them into account is necessary in order to design relevant public policies and to reach the Sustainable Development Goals.

First, climate changes will impact crop production, especially in areas of the world like the Sahel where agriculture is rainfed and thus depends a lot on rainfall variations. Temperature increase plays also a non-negligible role as it increases potential evapotranspiration and can 
shorten crop cycle (Sultan et al. 2013 for cereals in West Africa). The global warming caused by the increase temperature is expected to cause a serious perturbation of hydrological cycle elements like increase in atmospheric water vapour, shifting precipitation patterns and changes in precipitation in the tropics. These phenomena are arousing a large debate and much uncertainties on the temporal and spatial variabilities of rainfall events (Adhikari et al. 2014; Challinor and Wheeler 2008). Thus, climate impacts on crop productivity are expected to be negative in many tropical regions like East or West Africa for major crops: maize, sorghum, millet, groundnuts (Schlenker and Lobell 2010; Roudier et al. 2011: Sultan et al. 2013), whilst regions such as northern Australia and Indonesia may be able to expand and diversify production due to the relative stability of rainfall in these regions, and the expansion of the tropics into areas that are currently unable to support tropical crops, to the south.

\subsection{Impacts on soils}

Fifty percent of the worlds' agricultural soils are degraded, yet there is a need to rapidly increase food production to satisfy a growing population. Most of the acceleration in agricultural production is expected to occur in tropical regions, where tensions between increasing urbanisation, nature conservation, and land clearing for agriculture are especially strong. It has long been known that land clearing for agriculture increases nitrous oxide emissions from soils (Luizão et al. 1989) and is commensurate with increased soil acidification due to ion pumping interruptions (Tighe, et al. 2009) and soil structural decline (Guo and Gifford 2002).

Tropical horticultural soils have primarily developed under conditions of high rainfall, and hence liable to leaching and increased availability of iron, aluminium and manganese. Climate change will increase storms and rainfall events in many parts of the tropics, leading to localised 
leaching and waterlogging of high clay and volcanic soils. These soils, which are moderately acidic, will thus experience further declines in $\mathrm{pH}$ and as such, there is an increased risk of ion toxicity to crops. Substantial inputs of lime and other soil conditioners will be required to reverse soil acidification due to increased rainfall events and waterlogging.

Soil erosion and depletion will be a further consequence of climate change and estimated mean annual soil erodibility has shown a clear climate effect (Salvador-Sanchis et al. 2008), with distinctly different erosional patterns affecting soils in wet and dry tropics, as opposed to those in temperate areas. Possible explanations for distinctly different erosion patterns include soil laterisation and sesquioxide dynamics in tropical soils, as well as the larger infiltration rates of clay soils due to year-round warm temperatures (Borselli et al. 2012). In regions of the tropics that are becoming increasingly arid, a switch between chemical weathering and fluvial erosion to physical weathering and aeolian erosion is expected. As climate change will result in increased wind speeds, farmers will need to reconsider clearing all available air for food production, lest there be no windbreaks or soil coverage by plastic sheeting, cover crops or residue to prevent wind erosion.

Soil compaction is exacerbated by frequent wet-dry oscillations which cause structural decline in tropical soils. Consequently, soils become increasingly impermeable to oxygen and the movement of water, both of which increase risks of soil-borne fungal and bacterial diseases in warm climates (Ishak et. al. 2013). The disease-soil-plant cycle is poorly understood, but certainly in the context of wet-dry oscillations, the negative effects of climate change the quantity and distribution of freshwater, are expected to outweigh the benefits of overall increases in global precipitation due to a climate change (Thornton et al. 2014). Central-West Asia, North Africa, Asia and North America, are likely to be particularly affected by reduced 
freshwater availability (Rosegrant et al. 2009) as severe water constraints become apparent by 2050 (Rockström et al. 2009).

Organic carbon sequestration will be significantly affected depending on soil texture and structure, rainfall, temperature (Lal 2004a). Soil temperature might affect carbon decomposition of soils and even though much work has been conducted, still a consensus has to emerge on the temperature sensitivity of soil carbon decomposition (Davidson and Janssens 2006). Potentially, tropical soils could also lose fertility in a shorter time caused by the destruction of the tropical forest, and in the tropics cropland suitability will be lost consequently to climate (Ramankutty et al. 2002), while organic soils (peats) drying caused higher temperatures might result in high loss rates of soils carbon (Schimel et al. 1994). This high loss of organic matter has shown to be correlated with a low maintenance of availability of some mineral nutrients in soils (Maranguit et al. 2017). On the other hand, climate change and global warming have also shown to affect soils respiration in the tropics, and this increased respiration likely provides a positive feedback to the greenhouse effect (Raich and Schlesinger 1992). Thus, whilst frequent tillage will cause a net loss of C (Bajgai et al. 2015a, 2015b), residue incorporation to increase organic matter content can also enhance and accelerate soil respiration rates (Bajgai et al. 2013).

In this context, it is admitted that soil $\mathrm{C}$ sequestration plays a major role in carbon cycle and contributes to restore degraded soils, biomass production water purification, as well as reducing $\mathrm{CO}_{2}$ atmosphere-enrichment (Batjes 1996; Lal 2004b). Therefore, increasing soil C sequestration through improving the productivity and sustainability of existing agricultural lands might be considered as a significant mitigation (Paustian et al. 1997). Importantly, the role of microbial biomass carbon in the aggregation of soil, the transformation of $\mathrm{C}$ and the 
availability of nutrients shows is significant in the labile pool of tropical agricultural soils, and can be efficiently conserved and manipulated for its functional attributes when conservation tillage practices are implemented in farming systems ( $\mathrm{Li}$ et al. 2018). Nonetheless, SOC increases require careful interpretation to assess whether or not they represent genuine climate change mitigation as opposed to redistribution of organic $\mathrm{C}$ within the landscape or soil profile (Powlson et al. 2016).

\subsection{Pests and diseases}

The expansion of the wet tropics into the northern and southern hemisphere as the global climate changes will result in range expansion of many tropical pests and diseases and their vectors (Bebber et al. 2013). Northern Australia as is vulnerable to invasion from weeds, pests and diseases given its close proximity to New Guinea and the Indonesian archipelago which are both 'true' tropical environments (Scott et al. 2014). The frequency and wind speeds of tropical cyclones in northern Australia could accelerate as much as 10\% (Ash 2007), potentially increasing the likelihood of wind-borne weeds, pests and pathogens from countries further north (Scott et al. 2014). Anticipated impacts and therefore the vulnerability of production systems depend largely on species mixes, crops grown in the savanna, feed resources for livestock-cropping systems and feeding strategies (Thornton et al. 2009).

Rainfall and temperature interactions and their impacts on disease transmission are complex. However, major diseases of smallholder crops in Africa are likely to be associated with changes in rainfall - Maize Streak Virus and Cassava Mosaic Virus will predominate areas with increased rainfall, and Sorghum Head Smut (a fungal disease) will be likely in areas where rainfall decreases (Chancellor and Kubirba 2006). Even in areas where rainfall is far less of a problem, intense heat and insolation are likely to both enhance the vulnerability of coffee 
plantations, but also leave these and other crops susceptible to increased disease burden (Fain et al. 2017). Finally, increased levels of atmospheric carbon dioxide have a part to play in Fusarium spp. pathogenesis in grain crops such as wheat (Tiedemann and Firsching 2000), which are already marginal in most parts of the tropics due to the dramatically shrinking 'cold' season that allows some staple crops to be grown in India and Australia.

When an acute spike in temperature and atmospheric $\mathrm{CO}_{2}$ occurred between the Paleocene and Eocene epochs, the linked climatic shifts resulted in an increased percentage of damaged leaves and diversity of damage by insect herbivores (De Lucia et al. 2008). Decreases in native agrobiodiversity could substantially increase risk of crop failure from extreme climatic events and increase crop vulnerability to disease (Garrett 2008). In fact, even a short change in seasonal link can dramatically increase the proportion of parasitic insects, leading to increased defoliation of tree and fodder crops by insect pests.

Because we are not yet able to fully appreciate the relationship between the changing climate and the likelihood of disease (Chakraborty and Newton 2014), some researchers have considered reporting impacts using indirect methods, such as farmer surveys. In the context of rice production, diseases that arose due to increased and unexpected waterlogging carried through into storage facilities, were shown to impact up to a quarter of the harvested yield almost $90 \%$ of the time, whilst the risk of losing between half- to three-quarters of household income due to a significant disease outbreak was double that of risks associated with cyclones and severe flooding (Table 2).

\section{<Insert Table 2 here $>$}


Plant pests and diseases could potentially reduce yields of major crops by $50 \%$. These losses are even more significant in developing regions or regions heavily dependent on subsistence livelihoods. Average losses of rice in the period 2001-2003 totalled 37.4\%, of which $15 \cdot 1 \%$ was due to invertebrate pests, $10 \cdot 8 \%$ because of fungal and bacterial pathogens $10.2 \%$ from weeds and $1.4 \%$ due to viruses (Oerke 2006). Each year an estimated 10-16\% of global harvest (Strange and Scott 2005; Oerke 2006) is lost to plant diseases.

\subsection{Crop and varietal impacts}

Climate change is also constraining regional production, productivity and yield of major crops, and plants have been categorized into two groups: (i) plants that will be affected negatively by $\mathrm{CC}$ and considered as "losers', and plants that will benefit from $\mathrm{CC}$ and considered as "winners". Any significant yield decrease in tropical agricultural zones is primarily due to the temperature rise in more arid regions like the Mediterranean and the Middle East, versus the impacts of soil structural decline and poor root system development in regions that will experience more extreme rainfall events such as northern Australia, South East Asia, and the Gulf of Mexico (Pandey, et. al. 2016). It is important to emphasise that these general statements about crop productivity cannot be extended to all crops without in-depth analysis, however, it is acknowledged that yield decreases will be more significant in the tropical regions compared to the temperate ones, even though these late will undergo similar impact on yields (Berg et al 2012).

Globally, different scenarios have been developed to predict the decline in crop production and yields. As shown in Table 2, decline in yield varies and it is clear that some regions will be more affected than others, and the decline in cereals is more significant than other crops. However, some crops have been reported to be more resilient and the decline is predicted to be 
much less than less or non-resilient crops such cereals. In their review on impact of climate change on major crops in eastern Africa, Adhikari et al. (2014) reported that wheat yield will decline by $72 \%$, maize, rice and soybean by c.a. $45 \%$, while millet and sorghum yield, considered as more resilient, will decline by $<20 \%$. In their review, the same authors reported that sweet potato, potato and cassava will be less affected by climate change, and will have their yield varying from $-15 \%$ to $+10 \%$. Other crops such tea and coffee will have their yield declining by up to $40 \%$ and similar loss will be observed on banana and sugarcane production. Similar results have been reported by Tito et al. (2018) who indicated that increases risk of crop yield losses and food insecurity in the tropical Andes. They indicated that an increase by $1.3^{\circ} \mathrm{C}$ and $2.6{ }^{\circ} \mathrm{C}$, will cause a decline of maize and potatoes yield by $>87 \%$. Even though these crops are cultivated at higher altitudes, maize production decline ranged between $21 \%$ and $29 \%$ in response to new soil conditions.

\section{<Insert Table 2 here>}

Consequently, it is urgent to think how (i) to sustainably increase farm productivity in order to secure enough food for our growing population, (ii) strengthening resilience to climate change and variability, since climatic disruption needs copping and resilient agrosystems, alleviate global warming by reducing greenhouse gas emissions (Challinor et al. 2009; Howden et al. 2007), last and least planning adaptations in agricultural water management (Cai et al. 2015a, 2015b).

\subsection{Vulnerability of tropical crops to climate change}


Vulnerability of a tropical crop production system or of farming practices can be described as the net difference between the impacts driven by climate change, and the ability to adapt, or as described by (Kelly and Adger 2000) vulnerability is the capacity of people and social groups to respond to, recover from and adapt to stresses placed on their livelihoods and well-being. Environmental pressures on tropical agroecosystems driven by increased agricultural demand will result in asymmetrical declines in ecosystem services depending on future management trajectories and adaptive capacity of land managers (Goldsmith and Cohn 2017; Schlenker and Lobell 2010; Williams and Jackson 2007). Ultimately the vulnerability and sensitivity of tropical farming to climate change depends on the type of production system used, with tropical agricultural systems being more vulnerable due to a high concentration of developing nations and populations, primarily dependent on rain-feed systems (Battisti and Naylor 2009).

The climate in northern Australia is highly varied ranging from arid in the south to monsoonal in the far north and humid tropical in the east (Willcocks and Young 1991). Given the high variability of tropical cyclones in northern Australia, the region comparably to other continents in the tropics receives the highest variation in annual rainfall from less than 100 millimetres to over 2000 millimetres (Dewar and Wallis 1999). This variability in climate across the north Australian tropics has facilitated the emergence of various tropical crop production systems from cattle grazing to tropical fruits and sugarcane. These industries are now facing unprecedented challenges as the effects of climate change continue to rise - many stakeholders within Australia and elsewhere in the tropics are autonomously adjusting to climate change (Parry and Carter 1998).

Australia provides a suitable of example of how livestock grazing and cropping cycles have benefited from tropical climates, but Australia is also faced with challenging circumstances 
driven by extremes in the climate within the tropics. The expected impact of climate change on the pastoral production system in the savannas of northern Australia include changes in weed and increased woody vegetation distribution (Burrows 1995, McHenry et al. 2009; O'Rourke et al. 1992), which reduce farm productivity by means of invading and smothering crops or poisoning livestock in these areas (Hall et al. 1998; Tothill and Gillies 1992).

To feed the current world population more than $8000 \mathrm{~km}^{3} \mathrm{yr}^{-1}$ of freshwater is used in rain fed and irrigation agricultural production systems (Rost et al. 2008) which are commonly used in arable, mixed, subsistence and commercial farming systems. It is estimated that about $5000 \mathrm{~km}^{3}$ $\mathrm{yr}^{-1}$ more freshwater will be required by the year 2050 (Grubler 2007). There has been an increase in cultivated land in tropical to tropical-arid regions based on a rising population (Mongi et al. 2010). There are other production systems also affected by a changing climate such as rain-fed or irrigation agricultural methods. Rain-fed agriculture suffers more severely from the influence of climate change compared to irrigated agriculture (Xie et al. 2011). About $80 \%$ of total agriculture is carried out using the rain fed production method, and today this production system provides about $62 \%$ of the world's staple food (Bhattacharya 2008) and therefore current challenges facing rain fed agriculture is a serious concern in agriculture. Ongoing droughts, seasonal shift, increasing temperatures are described by farmers as being imminent challenges facing production in rain fed agricultural systems (Mongi et al. 2010).

Agriculture, as compared to other sectors, is the largest in terms of its water consumption and accounts for more than $70 \%$ of water withdrawn from freshwater storage points (Ashour and Al-Najar 2012). Therefore, changes in water availability likely increase the exposure of rainfed farming methods to climate change vulnerability in the tropics. Rice requires large volumes of water to grow in that it receives about $35-45 \%$ of the world's irrigation water. Although 
evidence suggests that while rice is water demanding, with good water conservation strategies water can be preserved in times of need like drought and can re-enter the hydrological cycle in tropical regions (Bouman n.d.). Rain-fed agriculture already struggles to meet agricultural demands, particularly in commercial farming systems, producing a lower yield than is needed to feed an increasing population largely attributed to a global climate change and a shortage of water available for irrigation (Anderson et al. 2016).

However, in the Central Highlands and Southern Delta of Vietnam there is a good example of how water conservation strategies in the face of climate change can aid both commercial and smallholder farmers in overcoming problems associated with a changing climate, such as drought. In recent years this region of Vietnam has been suffering an unprecedented drought and the coffee plant has suffered as a result seeing yields drop considerably. Established water saving technology providing individual coffee plants with automatically adjusted volumes of water in drought conditions has not only conserved water, but has saved considerable coffee yields for farmers in these affected tropical regions (World Bank 2016).

Maize production in tropical Mexico as another example where extensive drought conditions have resulted in decreased yields in one of the most important rain-fed agricultural production systems in Mexico (Conde and Ferrer 2006). Climate change has been identified as a potential culprit in the intensification of El Niño events (Cho 2016) and therefore the onset of drought conditions in the tropics (Conde and Ferrer 2006). In Indonesia projected delays in monsoons of up-to 30 days are resulting in a reduction in the yield of rice varieties (Naylor et al., 2007) due to drought. Other issues farmers are facing in the tropics for rice production include intrusion of sea water in dry seasons and increased salinity in the soil as a result (United Nations, 2014). As an example, farmers in Vietnams' Mekong Delta have seen hectares of 
watermelon, peanuts, rice and sweet potatoes become inundated from intruding sea water contaminating irrigation canals (United Nations 2014). The intruding saline water has seen reductions in yield as much as 50\% (United Nations 2014).

\section{<Insert Figure 3 here>}

\subsection{Impacts and consequences of climate changes on tropical crop production systems}

These climatic changes may have several impacts on cropping systems. Taking them into account is necessary in order to design relevant public policies and to reach the Sustainable Development Goals.

\subsubsection{Climate changes and crop productivity}

Climate changes will impact crop productivity, especially in areas of the World like the Sahel where agriculture is rainfed and thus depends a lot on rainfall variations. Temperature increase plays also a non-negligible role as it increases potential evapotranspiration and can shorten crop cycle (Sultan et al. 2013 for cereals in West Africa). Thus, climate impacts on crop productivity are expected to be negative in many tropical regions like East or West Africa for major crops: maize, sorghum, millet, groundnuts (Challinor et al. 2014; Roudier et al. 2011; Schlenker and Lobell 2010; Sultan et al. 2013). The significant yield decrease is mainly due to the temperature rise (Challinor et al. 2014); a rainfall decrease would of course aggravate this change but an increase could not completely offset this negative effect due to warming (Sultan et al. 2013).

It is fundamental to underline that these results cannot be extended to all crops without in-depth analysis. Indeed, another parameter - namely the Carbon fertilization effect - plays a major 
role for future crop production assessment (Leakey et al. 2009). For C3 crops (like soybean, rice, wheat) higher $\mathrm{CO}_{2}$ concentrations in the future could be physiologically beneficial for some crops through the stimulation of photosynthesis and reduction of drought stress resulting from lower stomatal conductance (Tubiello et al. 2007) and thus offset climate change negative effect. This positive $\mathrm{CO}_{2}$ effect is however controversial in the scientific community as some researchers underline that it could also be beneficial for weeds. Others show that the projected atmospheric ozone increase could also offset this $\mathrm{CO}_{2}$ effect (but ozone is currently not taken into account in crop models). Finally, it is necessary for C3 crops assessment to include both scenarios: with and without $\mathrm{CO}_{2}$ effect. This unfortunately increases considerably the uncertainty of future projections (Muller et al. 2015; Roudier et al. 2011). For example, McGrath and Lobell (2013) demonstrate that in Southern Africa the Carbon fertilization effect on sweet potatoes yields is over $+20 \%$ for a $100 \mathrm{ppm}$ increase in $\mathrm{CO}_{2}$ concentration. However, Challinor et al. (2014) in a meta-analysis covering all tropical areas of the world show that there will be a significant yield decrease, even for rice and wheat, after a certain warming threshold (close to $+2^{\circ} \mathrm{C}$ of local warming) if there are no adaptation plans.

Concerning tuber crops, some articles highlight that cassava will suffer less from future climate change as it is well known to be drought and heatwave -tolerant (Jarvis et al. 2012). However, cassava is very sensitive to diseases (cassava brown streak virus, cassava mosaic disease etc.) and to excess of water: as emphasized by Hershey et al. (2012), future climate change could have a positive effect on both parameters and therefore decrease cassava yields (but losses due to diseases and excess of water are more difficult to simulate in crop models used typically for climate impact studies). 
It is important to note that most studies do not explicitly take adaptation into account. It means that they make the assumption that farmers will not change their current cropping practices with a changing climate (except sometimes changing sowing dates). Nevertheless, Challinor et al. (2014) highlight in tropical regions that adaptation could offset the effect of CC for rice (but not for maize). These papers also do not give details about the cultivars that are studied: they focus generally on "maize" or "rice" while hundreds of cultivars with contrasted characteristics do exist. Sultan et al. (2013) show for example that traditional millet and sorghum varieties are less impacted by temperature rising than improved ones, because of their photoperiod sensitivity.

There are fewer studies about the impact of future CC on tropical cash crops like cocoa than on staple crops. They are indeed more challenging to model and most of the existing crop models focus on rice, wheat, millet, etc. Still, some papers on specific tropical areas (e.g. West Africa) demonstrate that the overall suitability to grow cocoa in the region will decrease because of higher maximum temperature during the dry season (Schroth et al. 2016).

\subsubsection{Future climate change and crop quality (nutrients)}

In a global meta-analysis, Myers et al. (2014) considered many different cases (countries, crops, years) that focus on the impact of rising $\mathrm{CO}_{2}$ concentration on nutrients $(\mathrm{Zn}, \mathrm{Fe}$, Protein, Phytate). They show that there is a significant decrease with elevated $\mathrm{CO} 2$ for wheat, rice (only for $\mathrm{Zn}, \mathrm{Fe}$, protein), field peas and soybeans (only for $\mathrm{Zn}$ and Fe). For C4 crops like maize and sorghum, the results are not statistically significant. In a recent paper combining high $\mathrm{CO} 2$ concentration and increased temperature during FACE experiments, Usui et al. (2016) conclude also that this leads to a decrease in rice proteins. These results could have important implications for future food security. 


\subsubsection{Other types of impacts}

As described above, several research papers have focused on the impacts of climate change on crop yields or productivity. But little is known about the rest of the value chain like post-harvest losses or pests and diseases: this is an interesting way for future research. Moreover, indirect impacts such as sea-level rise (loss of land availability and soil salinization) are difficult to include even if their effects are already visible in some coastal areas like the Niayes in Senegal (Fare et al. 2017). Finally, weather shocks (at different scales) can also impact commodities prices, and therefore, farming systems.

\section{ADAPTATION AND MITIGATION MEASURES FOR CURBING NEGATIVE IMPACTS OF CLIMATE CHANGE ON TROPICAL AGRICULTURE SYSTEMS}

The $21^{\text {st }}$ century is marked by an unprecedented human demographic explosion and climate changes. Therefore, this is resulting in the acceleration in demand for food, pressures on the land in tropical regions as well as other regions. As described in other chapters, these climatic changes are having different negative impacts on soils, crops, and agrosystems.

In order to reduce risks of climate change to tropical crop production, land management strategies must include capability to resist impacts of disease, explore new varieties, and reduce dependency on water. Though strategies to combat climate change impacts in agriculture are often viewed through the separate lenses of adaptation and mitigation, the more often that both strategies are combined, the less likely that agricultural systems and the humans who depend on them, will be vulnerable.

Options to adapt span a wide variety of approaches designed to reduce system vulnerabilities and enhance the adaptive capacity of these systems to a changing climate (Harvey et al. 2014a). 
Sophisticated solutions are still quite expensive to implement and are largely restricted to developed and rapidly industrialising nations and include modified agro-engineering practices for irrigation and soil integrity, breeding for different environmental stresses, developing early warning systems, and establishing crop insurance systems. More broadly, all nations in the tropics may realise substantial production security via soil and water conservation practices, crop diversification, and improved tillage practices (Howden et al. 2007).

One of the issues of foremost importance in rain-fed agriculture is reduced soil moisture and therefore low soil fertility in agricultural soils, the result of poor rainfall distribution and prolonged drought periods (Barron et al. 2003; Gowing et al. 2003; Mongi et al. 2010). Poor soil moisture and increased temperature have been linked to increased soil salinity, another factor reducing crop yield and increasing irrigated water demand (Ashour and Al-Najar 2012). Coping strategies employed by farmers using rain-fed methods include varying planting dates, planting more resistant maize varieties, changing cultivars and applying agrochemicals (Conde and Ferrer 2006).

Innovation in rice is necessary to ensure ongoing security one of the most important cereal crops in the tropics. Shifts to salt tolerant or drought tolerant varieties are becoming common, alongside deep-water rice varieties to advance global rice production in regions to affected by sea level rise. The Three Tier Rice Production System is an example of such an adaptation strategy. Tier 1 facilitates a more sustainable farming system whereby minimal tillage and cover cropping is used to promote crop rotation techniques (Nath and Lal 2017). Tier I of this production system also utilises the littoral zone of the wetland system where agroforestry techniques to grow other species such as bamboo are used to create diversity in cash flow and product - this technique also allows farmers to make the most of available moisture in soils 
to promote higher yield. Tier II utilises the sub-littoral zone of the wetland where there has been a notable increase in the ability to better manage and control weeds, and Tier III is where deep water species are adopted in this production system. This system provides a prolonged tolerance to flood waters, a common issue associated with climate change, and this system provides an option for seedling transplantation without the need for tillage. This Tier III system commonly used in Cambodia, Thailand and India also providers opportunity for a conjunction with an aquaculture based production system (Nath and Lal 2017).

Rising seawaters have been particularly destructive to rice crops, and some government agencies and private groups have responded by planting mangroves to prevent seawater inundating costal crops (Nguyen, 2014). Investments from the Vietnamese Government also aim to improve irrigation canals and dykes. As temperatures continue to increase and relative sea level continues to rise, farmers producing crops in coastal or low-lying regions may need to transition to more salt-tolerant species. Aquaculture has even been suggested as a viable alternative for farmers currently subject to intrusion of saline waters resulting from sea level rise (United Nations 2014).

Mitigation options in tropical agriculture focus on actions, including those that increase carbon stocks above and below ground, reduce greenhouse gas emissions and/or actively avoid the deforestation and degradation of high-carbon natural systems for agricultural production (Smith et al. 2007; Wollenberg et al. 2012b).

Although tropical agrosystems were less investigated compared to temperate systems, often these agrosystems are misunderstood and therefore, not as well managed as the temperate agrosystems (Janzen 1973). Different approaches have been reported to curb negative impacts 
of climate changes on the tropical agrosystems. As these systems have higher levels of biodiversity conservation, this trait might mitigate changes in temperature and precipitation when combined with environmentally friendly and sustainable land use agroforestry systems which have potential to enhance biodiversity conservation (Perfecto et al. 2007a, 2007b). The conversion of agriculture to crop-pasture rotation (CPR) showed that the implementation of this model (CPR) proved to be a good strategy to mitigate soil GHG (global greenhouse gas) emissions in the tropics (Carvalho et al. 2013). For example, erosion caused by high rainfall has been mitigated by implementing sound practices of soil and vegetation management such as contour planting, no-till farming and use of vegetative buffer strips and these practices can reduce erosion by up to $99 \%$ (Labriere et al. 2015) and reduce $\mathrm{CO}_{2}$ soil emission (La Scala et al. 2005). In some tropical areas, negative impacts of climate change on tropical agrosystems might also be mitigated by reforestation, planting fruit trees or expanding small plantations, however, more research is needed to determine the advantages of agrosystems that combine trees with crops, and crops with animals, because these systems are increasingly recognized and promoted to improve sustainable use of tropical lands (Labriere et al. 2015; Locatelli et al. 2015; Nicholas 1988).

Moreover, appropriate management strategies of tropical agroforestry systems might also mitigate climate change by adopting climate-smart approaches, especially when going in parallel with a comprehensive system rehabilitation plans, and also if these systems are designed in a larger landscape context and appropriately managed (Harvey et al. 2014b; Ramakrishnan 1998).

There are many definitions of resilience to climate change. In this chapter, we use the following one, as suggested by the IPCC: the "ability of a system and its component parts to anticipate, 
absorb, accommodate, or recover from the effects of a hazardous event in a timely and efficient manner”. Furthermore, and as detailed by Douxchamps et al. (2017), resilience is generally defined by its three capacities: absorptive (for a cropping system, for example its capacity to absorb a rainfall deficit without changing its fundamental structure), adaptive (capacity to adapt the cropping practices to the changing climate based on experience, observations) and transformative (capacity to change the cropping system to something different because the initial system cannot work anymore). In Sahelian farming systems, there are a diverse local practices and innovations that are increasing their resilience to $\mathrm{CC}$. We list below three examples illustrating the three types of capacities:

- Water harvesting techniques (WHT) (absorptive capacity). In many areas where agriculture is rainfed and dry spells are frequent, farmers have designed in-field WHT in order to mitigate droughts effects (see e.g. Biazin et al. 2012) for a review). One well-known WHT is Zai pits, initially used in Burkina Faso, that collect on-field runoff water. Generally, these WHT can increase the root zone soil water content by up to $30 \%$ (Biazin et al. 2012) as well as the soil organic matter content (Olaleye et al. 2006) ${ }^{1}$. These practices lead therefore to improved yields and lower risks of bad harvest (or crop failure) in case of dry spell.

- Cultivars diversity (adaptive capacity)

As already detailed before, for a specific type of crop (e.g. millet), there are many different cultivars with specific characteristics: drought and diseases resistance, cycle length, sensitivity to photoperiod...etc. Farmers have generally many cultivars available and choose the relevant one (or a mix of different types) in order to lower the 
risk of crop failure. For example, in the historical peanut basin of Senegal, Muller et al. (2015) report that long-term millet cultivars (Sanio) that disappeared after the 70s and 80 s droughts started to be grown again by farmers in order to benefit from wetter conditions occurring during the last years. The cultivar choice is also based on traditional seasonal forecasts systems that focus on the observation of natural phenomenon or on scientific forecasts when they are available (Roudier et al., 2014).

\section{- Crops \& income diversification (transformative capacity)}

Another option close to cultivars choice but that implies more structural changes is crop diversification. Indeed, farmers may grow new types of crops. For instance, in the former example in Senegal, some of them decided to start growing rainfed rice to benefit from the more humid years; in Côte d'Ivoire and Ghana, farmers growing cocoa can start planting trees in order to provide shade (beneficial for cocoa under warming conditions) and to provide another source of income. Generally, crop diversification is beneficial because it creates many co-benefits: climate risks mitigation, pests and diseases management, increased nutrient storage, increased yield stability...etc. (Lin 2011). In a recent analysis focusing on Zimbabwe, Makate et al. (2016) demonstrate that (i) $82 \%$ of the surveyed farmers practice crop diversification and (ii) increasing crop diversification has a positive significant impact on crop productivity and income. More broadly, income diversification (including non-agricultural work) is another wellknown risk management strategy for farmers. Still in Zimbabwe, Ersado (2003) highlights that income diversification is particularly high in rural areas and are essential tools to mitigate price and weather shocks on the agricultural sector. 
Many of the previous practices (as well as others like the use of meteorological and seasonal forecasts) are grouped under the terminology of agroecological practices (Altieri et al. 2015) that is recognized (i) to increase farming system resilience to climate change but also (ii) to reduce GHG emissions coming from agriculture (close to $25 \%$ of global $\mathrm{CO} 2$ emissions). Agroecological practices are however often put in place at a very small scale and could be difficult to promote in areas where intensive agriculture is the dominant model. It is therefore necessary to (i) go on demonstrating what the benefits of agroecology are in terms of income, food security, environmental externalities, (ii) broadcast evidence of such practices usefulness (workshops, education) and (iii) design appropriate regional and national policies in order to scale up local good practices (Parmentier 2014).

\section{CONCLUSIONS AND PERSPECTIVES}

In conclusion, evidence shows that the climate is significantly changing on a global scale and this will, if not already started, have significant impacts on tropical agrosystems and consequently affect food supply in the tropics, and this will make some tropical countries in the tropics more vulnerable in particular. Unless measures and decision are taken to mitigate the negative effects of climate change on these vulnerable agrosystems, food production in the tropics will be under threat, as well. In the tropics, the temperature is going to rise significantly because of GHG emissions and rainfall changes are expected if many regions of the World (e.g. decrease in Southern Africa) even if the uncertainty is high for some areas (West Africa). These changes will impact crop production and crop nutrients concentration. Some crops are expected to be significantly negatively impacted like maize. For $\mathrm{C} 4$ crops like rice situation is more uncertain but their nutrients concentration will probably decrease because of elevated $\mathrm{CO}_{2}$. Therefore, and beside mitigating actions, resilience of the systems that could be 
strengthened by agroecological practices, and agroecology which is often localized at the project scale and must be scaled-up through appropriate public policies.

The future prospective is focus on (i) studying more largely the impacts of future climate change on the whole value chain (not only production), (ii) assess the impacts of agroecological practices on income, food security, GHG emissions, (iii) focus on inequalities (especially gender inequalities), and (iv) design relevant policies to scale up agroecology, including education. Furthermore, we also need to adopt of specific strategies to not only mitigate the negative impacts of climate changes on the tropical agrosystems, but also these strategies should also partly reverse the negative impacts and the degradation process caused by the climate change factors. 


\section{REFERENCES}

Adhikari, U, P. A. Nejadhashemi, and S. A. Woznicki. 2015. Climate change and eastern Africa: a review of impact on major crops. Food Energy Sec 4:110-32.

Altieri, M. A., C. I. Nicholls, A. Henao, et al. 2015. Agroecology and the design of climate change-resilient farming systems. Agron Sustain Dev 35:869-90.

Anderson, W., C. Johansen, and K. Siddique. 2016. Addressing the yield gap in rainfed crops: a review. Agron Sustain Dev 36:18. https://doi.org/10.1007/s13593-015-0341-y.

Ash, A. 2007. Climate change impacts and adaptation in Northern Queensland. CSIRO, Australia. https://www.planning.org.au/documents/item/160. (accessed: 14 January 2018).

Ashour, E., and H. Al-Najar. 2012. The impact of climate change and soil salinity in irrigation water demand in the Gaza strip. $J$ Earth Sci Clim Change 3:2. https://doi.org/10.4172/2157-7617.1000120.

Australian $\quad$ Government, 2017. Weeds in Australia. http://www.environment.gov.au/biodiversity/invasive/weeds/weeds/why/impact.html. (accessed: 17 January 2018).

Bagley, J., A. Desai, K. Harding, P. Synder, and J. Foley. 2014. Drought and deforestation: Has land cover change influenced recent precipitation extremes in the Amazon? $J$ Clim 27:345-61.

Bajgai, Y., Hulugalle, N., Kristiansen, P. and McHenry, M., 2013. Developments in fractionation and measurement of soil organic carbon: A Review. Open Journal Soil Sci 3(08): 356-360 http://dx.doi.org/10.4236/ojss.2013.38041

Bajgai, Y., P. Kristiansen, N. Hulugalle, M. McHenry, and B. McCorkell. 2015a. Soil organic carbon and microbial biomass carbon under organic and conventional vegetable cropping systems in an Alfisol and a Vertisol. Nut Cycl Agroecosyst 101:1-15. 
Bajgai. Y, P. Kristiansen, and M. McHenry. 2015b. Comparison of organic and conventional managements on yields, nutrients and weeds in a corn-cabbage rotation. Renew Agr Food Syst 30:132-42.

Barron, J., J. Rockstrom, F. Gichuki, and N. Hatibu. 2003. Dry spell analysis and maize yields for two semi-arid locations in East Africa. Agric Meteorol 117:23-37.

Battisti, D. S., and R. L. Naylor. 2009. Historical warnings of future food insecurity with unprecedented seasonal heat. Science 323:240-4.

Baylis, M., and A. Githeko. 2006. The effects of climate change on infectious diseases of animals. No. 35. Report for the Foresight Project on Detection of Infectious Diseases, Department of Trade and Industry, UK.

Batjest, N. H. 1996. Total carbon and nitrogen in the soils of the world. Eur J Soil Sci 47:15163.

Bebber, D. P., M. A. Ramotowski, and S. J. Gurr. 2013. Crop pests and pathogens move polewards in a warming world. Nature Clim Chang 3:985-88.

Benkeblia, N. 2012. Sustainable agriculture and new biotechnologies. Boca Raton (FL): CRC Press.

Berg, A., N. de Noblet-Ducoudré, B. Sultan, M. Lengaigne, and M. Guimberteau, 2012. M. Projections of climate change impacts on potential C4 crop productivity over tropical regions. Agr Forest Meteorol 170:89-102.

Bhattacharya, A. 2008. Sustainable Livelihood Based Watershed Management - Watershed Plus Approach. Presented at the $2^{\text {nd }}$ Working Group meeting of ERIA, IGES, Japan.

Biazin, B., G. Sterk, M. Temesgen, A. Abdulkedir, and L. Stroosnijder. 2012. Rainwater harvesting and management in rainfed agricultural systems in sub-Saharan Africa - a review. Phys Chem Earth 48:139-51. 
Bodin,

G. 2017 .

Traditional

agriculture

https://www.dahu.bio/en/knowledge/agriculture/traditional-agriculture. (accessed: 6 June 2017).

Bouman, D. B. n.d. Does rice really use too much water? International Rice Research Institute. http://irri.org/blogs/bas-bouman-s-blog-global-rice-science-partnership/does-ricereally-use-too-much-water. (accessed: 14 January 2018).

Burrows, W., 1995. Greenhouse revisited - land-use change from a Queensland perspective. Clim Chang Newslett 7:6-7.

Cai, X., X. Zhang, P. H. Noël, and M. Shafiee-Jood. 2015a. Impacts of climate change on agricultural water management: a review. WIRES Water 2:439-55.

Cai, W., G. Wang, A. Santoso, et al. 2015b. Increased frequency of extreme La Ninaevents under greenhouse gas warming. Nat Clim Chang 5:132-7.

Campbell, B. M., S. J. Vermeulen, P. K. Aggarwal, et al. 2016. Reducing risks to food security from climate change. Glob Food Secur 11:34-43.

Carvalho, J. J. N., G. S. Raucci, L. A. Frazão, C. E. P. Cerri, M. Bernoux, and C. C. Cerri. 2013. Crop-pasture rotation: A strategy to reduce soil greenhouse gas emissions in the Brazilian Cerrado. Agr Ecosyst Environ 183:167-75.

Chakraborty, S. A. C., and Newton. 2011. Climate change, plant diseases and food security: an overview. Plant Pathol 60:2-14.

Challinor, A. J., J. Watson, D. B. Lobell, S. M. Howden, D. R. Smith, and N. Chhetri. 2014. A meta-analysis of crop yield under climate change and adaptation. Nat Clim Chang 4:287-91.

Challinor, A. J., F. Ewert, S. Arnold, E. Simelton, and E. Fraser. 2009. Crops and climate change: Progress, trends, and challenges in simulating impacts and informing adaptation. $J$ Exp Bot 60:2775-89. 
Challinor, A. J., and T. R. Wheeler. 2008. Crop yield reduction in the tropics under climate change: Processes and uncertainties. Agr Forest Meteorol 148:343-56.

Chancellor, T., and K. Kubiriba. 2006. The effects of climate change on infectious diseases of plants. Review for UK Government Foresight Project, Infectious Diseases—Preparing for the Future. Department of Trade and Industry, London.

Chang, C. 2002. The potneital impact of climate change on Taiwan's agriculture. Agric Econ 27:51-64.

Cho, R. 2016. El Nino and global warming - What's the Connection? State Planet - Earth Institute, Columbia University. http://blogs.ei.columbia.edu/2016/02/02/el-nino-andglobal-warming-whats-the-connection/. (accessed: 25 October 2017).

Christensen, J. H., K. Krishna Kumar, E. Aldrian, et al. 2013: Climate phenomena and their relevance for future regional climate change. In Climate Change 2013: The Physical Science Basis. Contribution of Working Group I to the Fifth Assessment Report of the Intergovernmental Panel on Climate Change, ed. T.F. Stocker, D. Qin, G. K. Plattner, et al. Cambridge: Cambridge University Press. https://www.ncdc.noaa.gov/sotc/global/201704. (accessed: 9 June 17).

Conde, C., and R. Ferrer. 2006. Climate change and climate variability impacts on rainfed agricultural activities and possible adaptation measures: A Mexican Case Study. Atmosfera 19:181-94.

Darwin, R., and D. Kennedy. 2000. Economic effects of $\mathrm{CO} 2$ fertilization of crops: transforming changes in yield into changes in supply. Environ Model Assess 5:157-6.

Dasgupta, S., B. Laplante, C. Meisner, D. Wheeler, and J. Yan. 2007. The impact of sea level rise on developing countries: A comparative analysis. Policy Research Working Paper; No. 4136. World Bank, Washington, DC. 
https://openknowledge.worldbank.org/handle/10986/7174. (accessed: 20 October 2017).

Davidson, E. A., and I. A. Janssens. 2006. Temperature sensitivity of soil carbon decomposition and feedbacks to climate change. Nature 440:165-73.

De Lucia, E. H., C. L. Casteel, P. D. Nabity, and B. F. O’Neill. 2008. Insects take a bigger bite out of plants in a warmer, higher carbon dioxide world. Proc Natl Acad Sci USA $105: 1781-2$

Denevan, W. 1995. Prehistoric agricultural methods as models for sustainability. Adv Plant Pathol 11:21-43.

Déqué, M., S. Calmanti, O. B. Christensen, et al. 2016. A multi-model climate response over tropical Africa at $+2{ }^{\circ} \mathrm{C}$. Clim Serv 7:87-90.

Dewar, R., and J. Wallis. 1999. Geographic patterning of interannual rainfall variability in the tropics and near-tropics. J Clim 12:3457-66.

Douxchamps, S., L. Debevec, M. Giordano, and J. Barron. 2017. Monitoring and evaluation of climate resilience for agricultural development - A review of currently available tools, World Dev Persp 5:10-23

Ersado, L. 2003. Income diversification in Zimbabwe: welfare implications from urban and rural areas. Food Consumption and Nutrition Division Discussion Paper No. 152. $\begin{array}{llll}\text { International } & \text { Food } & \text { Policy } & \text { Research }\end{array}$ https://ageconsearch.umn.edu/bitstream/16467/1/fc030152.pdf. (accessed: 6 June 2017).

Endres, A., and R. Endres. 2017. The European Union, agriculture, and the tropics: Public financial incentives to enhance food security and expansion of production contracts. Trop Conserv Sci 10:1-4 
Fain, S. J., M. Quiñones, N. L. Álvarez-Berríos, I. K. Parés-Ramos, and W. A. Gould. 2018. Climate change and coffee: assessing vulnerability by modeling future climate suitability in the Caribbean island of Puerto Rico. Clim Chang 146:175-86.

FAO, 2017. Module 4: Crop production systems. FAO, Rome.

Fare, Y., M. Dufumier, M. Loloum, et al. 2017. Analysis and Diagnosis of the Agrarian System in the Niayes Region, Northwest Senegal (West Africa). Agriculture 7:59. DOI:10.3390/agriculture7070059 www.

FIBL-ITC, 2007. Organic farming and climate change. International Trade Centre, technical paper. $\quad$ http://orgprints.org/13414/3/niggli-etal-2008-itc-climate-change.pdf. (accessed: 6 June 2017).

Flannery, T. 2006. We are the weather makers. Melbourne: The Text Publishing Company.

Frey, T., M. Gelhausen, and M. Saake. 2011. Categorization of concerns - A categorical program comprehension model. Proceedings of the Workshop on Evaluation and Usability of Programming Languages and Tools (PLATEAU), ACM Onward and SPLASH Conferences. Portland, Oregon, USA.

Garrett, K. A. 2008. Climate change and plant disease risk. In Global climate change and extreme weather events: understanding the contributions to infectious disease emergence, ed. D. A. Relman, M. A. Hamburg, E. R. Choffnes, and A. Mack, 143155. Washington DC: National Academies Press.

Gibbs, H., A. Ruesch, F. Achard, et al. 2010. Tropical forests were the primary sources of new agricultural land in the 1980s and 1990s. Proc Natl Acad Sci USA 107:16732-7.

Goldsmith, P., and A. Cohn. 2017. Commercial agriculture in tropical environments. Trop Conserv Sci 10:1-4. 
Gowing, J., M. Young, N. Hatibu, H. Mahoo, F. Rwehumbiza, and O. Mzirai. 2003. Developing improved dryland cropping systems for maize in semi-arid Tanzania. Exp Agric 9:293-306.

Grubler, A. 2007. Regional, national, and spatially explicit scenarios of demographic and economic change based on SRES. Technol Forecast Soc 74:980-1029.

Guo, L. B., and R. M. Gifford. 2002. Soil carbon stocks and land use change: a meta-analysis. Glob Chang Biol 8:345-60.

Hall, W., G. McKeon, J. Carter, et al. 1998. Climate change in Queensland's grazing lands: II. An assessment of the impact on animal production from native pastures. Rangel J 20: 177-205.

Hanson, J., B. Baker, and R. Bourdon. 1993. Comparison of the effects of different climate change scenarios on rangeland livestock production. Agric Syst 41:487-502.

Harvell, C., C. Mitchell, J. Ward, et al. 2002. Ecology - climate warming and disease risks for terrestrial and marine biota. Science 296:2158-62.

Harvey, C. A., M. Chacón, C. I. Donatti, et al. 2014a. Climate-Smart landscapes: Opportunities and challenges for integrating adaptation and mitigation in tropical agriculture. Conserv Lett 7:77-90.

Harvey, C., Z. Lalaina Rakotobe, N. Rao, et al. 2014b. Extreme vulnerability of smallholder farmers to agricultural risks and climate change in Madagascar. Philos $T R$ Soc B 369:20130089. http://dx.doi.org/10.1098/rstb.2013.0089.

Herne, B., 1998. U.S. Cattle cycle is the key to rising prices. Brigaletter 32:1-2.

Hershey, C.H., E. Alvarez, T. Maung Aye, et al. (2012). Eco-efficient interventions to support cassava's multiple roles in improving the lives of smallholders. Centro Internacional de Agricultura Tropical (CIAT), Cali. 
Hertel, T., Rosch, S., 2010. Climate change, agriculture and poverty. App Econ Perspect $P$ 32:1. https://doi.org/10.1093/aepp/ppq016.

Howden, M. S., J. F. Soussana, F. N. Tubiello, N. Chhetri, M. Dunlop, and H. Meinke. 2007. Adapting agriculture to climate change. Proc Natl Acad Sci USA 104:19691-6.

IFOAM, 2005. Organic agriculture definition. https://www.ifoam.bio/pt/organiclandmarks/definition-organic-agriculture (accessed 29 October 2017).

IFPRI, 2017. Smallholder farming. International Food Policy Research Institute. http://www.ifpri.org/topic/smallholder-farming. (accessed: 10 April 2017).

IPCC, 2007. Summary for policymakers of the synthesis report of the IPCC. Fourth Assessment Report (Assessment Report). Intergovernmental Panel on Climate Change, Geneva.

Ishak, L., M. McHenry, and P. Brown. 2016. Soil compaction and its effects on soil microbial communities in Capsicum growing soil. Acta Hortic 1123:123-30.

Ishak, L., M. T. McHenry, and P. H. Brown. 2013. Soil compaction in tropical organic Farming systems and its impact on natural soil-borne disease suppression: Challenges for management. Int J Econ Manag Eng 7:2926-8.

Janzen, D. H. 1973. Tropical agroecosystems. Science 182:1212-9.

Jarvis, A., J. Ramirez-Villegas, B. V. H. Campo, and C. Navarro-Racines. 2012. Is cassava the answer to African climate change adaptation? Trop Plant Biol 5:9-29.

Keeling, C., J. Chin, and T. Whorf. 1996. Increased activity of northern vegetation inferred from atmospheric $\mathrm{CO}_{2}$ measurements. Nature 382:146-9.

Kelly, P., and W. Adger. 2000. Theory and practice in assessing vulnerability to climate change and facilitating adaptation. Clim Chang 14:325-52. 
Kembe, M., C. Omondi, and G. Waga. 2016. The influence of socio-cultural characteristics on commercialization of smallholder dairy value chain development in Uasin Gishu Country, Kenya. J Geogr Reg Plan 9:164-75.

Khush, G. 2005. What it will take to feed 5.0 billion rice consumers in 2030. Plant Mol Biol $59: 1-6$.

Köppen, W. 1900a. Versuch einer Klassifikation der Klimate, vorzugsweise nach ihren Beziehungen zur Pflanzenwelt. Geogr Zeitschr 6:593-611.

Köppen, W. 1900b. Versuch einer Klassifikation der Klimate, vorzugsweise nach ihren Beziehungen zur Pflanzenwelt. Geogr Zeitschr 6:657-79.

Labrière, N., B. Locatellia, Y. Laumonier, V. Freycon, and M. Bernoux. 2015. Soil erosion in the humid tropics: A systematic quantitative review. Agr Ecosyst Environ 203:12739.

Läderach, P., A. Martinez-Valle, G. Schroth, and N. Castro. 2013. Predicting the future climatic suitability for cocoa farming of the world's leading producer countries, Ghana and Côte d'Ivoire. Clim Chang 119:841-54.

Lal, R. 2008. Carbon sequestration. Philos T R Soc B 363:815-30.

Lal, R. 2004a. Soil carbon sequestration impacts on global climate change and food security. Science 304:1623-7.

Lal, R. 2004b. Soil carbon sequestration to mitigate climate change. Geoderma 123:1-22.

La Scala, N., Jr. D. Bolonhezi, and G. T. Pereira. 2005. Short-term soil $\mathrm{CO}_{2}$ emission after conventional and reduced tillage of a no-till sugar cane area in southern Brazil. Soil Till Res 91:244-8.

Laurance, W., Sayer, J., Cassman, K., 2014. Agricultural expansion and its impacts on tropical nature. Trends Ecol Evol 29: 107-116. 
Leakey, A. D. B. 2009. Rising atmospheric carbon dioxide concentration and the future of C4 crops for food and fuel. Proc R Soc B Biol Sci 276:2333-43.

Lin, B. 2011. Resilience in agriculture through crop diversification: Adaptive management for environmental change. BioScience 6:183-93.

Locatelli, B., C. P. Catterall, P. Imbach, et al. 2015. Tropical reforestation and climate change: beyond carbon. Restor Ecol 23:337-43.

Luizão, F., P. Matson, G. Livingston, R. Luizão, and P. Vitousek 1989. Nitrous oxide flux following tropical land clearing. Global Biogeochem Cy 3:281-5.

Makate, C., R. Wang, M. Makate, and N. Mango. 2016. Crop diversification and livelihoods of smallholder farmers in Zimbabwe: Adaptive management for environmental change. SpringerPlus 5:1135. DOI: 10.1186/s40064-016-2802-4

Malhi, Y., and J. Wright. 2004. Spatial patterns and recent trends in the climate of tropical rainforest regions. Philos T R Soc B Biol Sci 359:311-29.

Maranguit, D., T. Guillaume, and Y. Kuzyakov. 2017. Land-use change affects phosphorus fractions in highly weathered tropical soils. Catena 149:385-93.

Mbagwu, J., Scott, T., 2000. Physical properties of three soils in southern Nigeria. Soil Sci $36: 48-55$.

McGrath, J. M., and D. B. Lobell. 2013. Regional disparities in the $\mathrm{CO}_{2}$ fertilization effect and implications for crop yields. Environ Res Lett 8:014054. DOI:10.1088/1748$9326 / 8 / 1 / 014054$

McDowell, J., and J. Hess. 2012. Accessing adaptation: multiple stressors on livelihoods in the Bolivian highlands under a changing climate. Glob Environ Change 22:342-52.

McHenry, M.T., B. R. Wilson, P. V. Lockwood, et al. 2009. The impact of individual Callitris glaucophylla (White Cypress Pine) trees on agricultural soils and pastures of the north-western slopes of NSW, Aust Rangel J 31:321-8. 
Mongi, H., A. Majule, and J. Lyimo. 2010. Vulnerability and adaptation of rain fed agriculture to climate change and variability in semi-arid Tanzania. Afr J Environ Sci Technol $4: 371-81$

Morton, J. 2007. The impact of climate change on smallholder and subsistence agriculture. Proc Natl Acad Sci USA 104:9680-5.

Moss, R. H., J. A. Edmonds, K. A. Hibbard, et al. 2010. The next generation of scenarios for climate change research and assessment. Nature 463:747-56.

Muller, A., 2009. Benefits of organic agriculture as a climate change adaptation and mitigation strategy for developing countries. Discussion Paper Series, Environment for $\begin{array}{llll}\text { Development, } & \text { EfD } & \text { DP-09. }\end{array}$ http://www.indiaenvironmentportal.org.in/files/benefitsoforganicagriculture.pdf. (accessed: 26 October 2017).

Muller, B., R. Lalou, P. Kouakou, et al. 2015. Le retour du mil sanio dans le Sine : une adaptation raisonnée à l'évolution climatique. In Les sociétés rurales face aux changements climatiques et environnementaux en Afrique de l'Ouest, ed. B. Sultan R. Lalou, S. Amadou, A. Oumarou, and M. A. Soumaré M.A, 377-401. Marseille: IRD Publications.

Müller, C., J. Elliott, J. Chryssanthacopoulos, et al. 2015. Implications of climate mitigation for future agricultural production. Environ Res Lett 10:125004. DOI:10.1088/1748$9326 / 10 / 12 / 125004$.

Myers, S. S., A. Zanobetti, I Kloog, et al. 2014. Increasing $\mathrm{CO}_{2}$ threatens human nutrition. Nature 510:139-42.

Myneni, R., C. Keeling, C. Tucker, G. Asrar, and R. Nemani. 1997. Increased plant growth in the northern high latitudes from 1981 to 1991. Nature 386:698-702. 
Nath, A., Lal, R., 2017. Managing tropical wetlands for advancing global rice production: Implications for land-use management. Land Use Pol 68:681-5.

Naylor, R. L., D. S. Battisti, D. J. Vimont, W. P. Falcon, and M. B. Burke. 2007. Assessing risks of climate variability and climate change for Indonesian rice agriculture. Proc Natl Acad Sci USA 104:7752-7.

Nguyen, A. L., Dang, V. H., Bosma, R. H., Verreth, J. A. J., Leemans, R., \& De Silva, S. S. 2014. Simulated Impacts of Climate Change on Current Farming Locations of Striped Catfish (Pangasianodon hypophthalmus; Sauvage) in the Mekong Delta, Vietnam. Ambio 43(8): 1059-1068. http://doi.org/10.1007/s13280-014-0519-6

Nicholas, I. D. 1988. Plantings in tropical and subtropical areas. Agr Ecosyst Environ 22/23: 465-82.

Nwagbara, M. 2015. Climate change and soil conditions in the tropical rainforest of Southeastern Nigeria. Am Res Inst Policy Dev 3:99-106.

Nwagbara, M. 2008. Landcover change in relation to climate change in northern Nigeria using GIS techniques. PhD Dissertation. Abia State University, Uturu, Nigeria.

Oerke, E. C. 2006. Crop losses to pests. J Agric Sci 144:31-43.

Olaleye, B., A. O. Barry, A. I. Adeoti, and D. Fatondji. 2006. Impact of soil water conservation and rainwater harvesting technologies on improving livelihoods Sahelian zone of West Africa. Sydney: Australian Society of Agronomy.

O’Rourke, P., L. Winks, and A. Kelly. 1992. North Australia beef producer survey 1990. Brisbane: Queensland Department of Primary Industries.

Park, S. 2008. A review of climate change impact and adaptation assessments on the Australian sugarcane industry. Proc Aust Soc Sugar Cane Technol 30:1-9.

Parmentier, S. 2014. Scaling-up agroecological approaches: what, why and how? Oxfam Discussion Paper. Oxfam-Solidarity, Belgium. https://ag-transition.org/wp- 
content/uploads/2014/01/201401-Scaling-up-agroecology-what-why-and-how-

OxfamSol-FINAL.pdf. (accessed: 26 October 2017).

Parry, M., C. Rosenzweig, A. Iglesias, G. Fischer, and M. Livermore, 1999: Climate change and world food security: A new assessment. Glob Environ Change 9:S51-7.

Parry, M., and T. Carter. 1998. Climate impact and adaptation assessment. London: Earthscan Publication Ltd.

Paustian, K., O. Andrén, H. H. Janzen, et al. 1997. Agricultural soils as a sink to mitigate $\mathrm{CO}_{2}$ emissions. Soil Use Manag 13:229-44.

Perfecto, I., I. Armbrecht, S. M. Philpott, L. Soto-Pinto, and T. M. Dietsch. 2007. Shaded coffee and the stability of rainforest margins in northern Latin America. In The stability of tropical rainforest margins, linking ecological, economic and social constraints of land use and conservation, ed. T. Tscharntke, C. Leuschner, M. Zeller, E. Guhadja, and A. Bidin, 227-264. Environmental Science Series. Berlin: Springer Verlag.

Perugini, L., L. Caporaso, S. Marconi, et al. 2017. Biophysical effects on temperature and precipitation due to land cover change. Environ Res Lett 12:053002. https://doi.org/10.1088/1748-9326/aa6b3f.

Philpott, S. M., P. Bichier, R. Rice, and R. Greenberg. 2007. Field testing ecological and economic benefits of coffee certification programs. Conserv Biol 21:975-85.

Ramakrishnan, P. S. 1998. Sustainable development, climate change and tropical rain forest landscape. Climatic Change 39:583-600.

Ramankutty, N., F. A. Foley, J. Norman J, and K. McSweeney. 2002. The global distribution of cultivable lands: current patterns and sensitivity to possible climate change. Global Ecol Biogeo 11:377-92.

Raich, J. W., and W. H. Schlesinger. 1992. The global carbon dioxide flux in soil respiration and its relationship to vegetation and climate. Tellus B 44:81-99. 
Rockström, J., M. Falkenmark, L. Karlberg, H. Hoff, S. Rost, and D. Gerten. 2009. Future water availability for global food production: the potential of green water for increasing resilience to global change. Water Res Res 45:1-16.

Rosegrant, M. W., M. Fernandez, A. Sinha, et al. 2009. Looking into the future for agriculture and AKST (Agricultural Knowledge Science and Technology). In Agriculture at a Crossroads, ed. B. D. McIntyre, H. R. Herren, J. Wakhungu, and R. T. Watson, 307376. Washington DC: Island Press.

Rosenzweig, C., J. Elliott, D. Deryng, et al. 2014. Assessing agricultural risks of climate change in the 21 st century in a global gridded crop model intercomparison. Proc Natl Acad Sci USA 111:3268-73.

Rosenzweig, C., and A. Iglesias. 1998. Theuseofcropmodelsfor international climate change impact assessment. In Understanding options for agricultural production, ed. G. Y. Tsuji, G. Hoogenboom, and P. K. Thornton, 267-292. Dordrecht: Kluwer Academic Publishers.

Rost, S., D. Gerten, A. Bondeau, W. Lucht, J. Rohwer, and S. Schaphoff. 2008. Agricultural green and blue water consumption and its influence on the global water system. Water Res 44:W09405. DOI:10.1029/2007WR006331.

Roudier, P., B. Sultan, P. Quirion, and A. Berg. 2011. The impact of future climate change on West African crop yields: What does the recent literature say? Glob Environ Change 21:1073-83.

Roudier, P., A. Muller, P. d'Aquino, et al., 2014. The role of climate forecasts in smallholder agriculture: Lessons from participatory research in two communities in Senegal. Clim Risk Manag 2:42-55.

Salvador Sanchis, M. P., D. Torri, L. Borselli, and J. Poesen. 2008. Climate effects on soil erodibility. Earth Surf Proc Land 33:1082-97. 
Schimel, D. S., B. H. Braswell, E. A. Holland, et al. 1994. Climatic, edaphic, and biotic controls over storage and turnover of carbon in soils. Global Biogeiochem Cy 8:279-93.

Schlenker, W., and D. B. Lobell. 2010. Robust negative impacts of climate change on African agriculture. Environ Res Lett 5:014010. DOI:10.1088/1748-9326/5/1/014010.

Schroth, G., P. Läderach, A. I. Martinez-Valle, C. Bunn, and L. Jassogne. 2016. Vulnerability to climate change of cocoa in West Africa: Patterns, opportunities and limits to adaptation. Sci Total Environ 556 :231-41.

Scott, J., B. Webber, H. Murphy, N. Ota, D. Kriticos, and B. Loechel. 2014. AdaptNRM Weeds and Climate Change: Supporting weed management adaptation (Technical Guide). Available at: www.AdaptNRM.org

Smith, P., D. Martino, Z. Cai, et al. 2007. Agriculture. In Climate change 2007: Mitigation. contribution of working group III to the fourth assessment report of the intergovernmental panel on climate change, ed. B. Metz, O. R. Davidson, P. R. Bosch, R. Dave, and L. A. Meyer, 498-540. Cambridge: Cambridge University Press.

Strange, R. N., and P. R. Scott. 2005. Plant disease: a threat to global food security. Annu Rev Phytopathol 43:83-116.

Sultan, B., P. Roudier, P. Quirion, et al. 2013. Assessing climate change impacts on sorghum and milletyields in the Sudanian and Sahelian savannas of West Africa. Environ Res Lett 8:014040. DOI:10.1088/1748-9326/8/1/014040.

Sylla, M. B., P. M. Nikiema, P. Gibba, I. Kebe, and N. A. B. Klutse. 2016. Climate change over West Africa: Recent trends and future projections. In Adaptation to climate change and variability in rural West Africa, ed. J.A. Yaro, and J. Hesselberg, 25-40. Cham: Springer International Publishing.

Thornton, P. K., P. J. Ericksen, M. Herrero, and A. J. Challinor. 2014. Climate variability and vulnerability to climate change: a review. Global Change Biol 20:3313-28. 
Thornton, P., J. van de Steeg, A. Notenbaert, and M. Herrero. 2009. The impacts of climate change on livestock and livestock systems in developing countries: A review of what we know and what we need to know. Agric Syst 101:113-27.

Tiedemann, A. V., and K. H. Firsching. 2000. Interactive effects of elevated ozone and carbon dioxide on growth and yield of leaf rust-infected versus non-infected wheat. Environ Pollut 108:357-63.

Tighe, M., N. Reid, B. Wilson, and S. V. Briggs. 2009. Invasive native scrub and soil condition in semi-arid south-eastern Australia. Agr Ecosyt Environ 132:212-22.

Tito, R, H. L. Vasconcelos, and K. J. Feeley. 2018. Global climate change increases risk of crop yield losses and food insecurity in the tropical Andes. Global Change Biol 24:e592-e602. DOI: 10.1111/gcb.13959

Tothill, J., and C. Gillies. 1992. The pasture lands of northern Australia: Their condition, productivity and sustainability. St Lucia (Qld.): Tropical Grasslands Society of Australia.

Trewin, B., 2017. Essay 1: The climates of the Tropics, and how they are changing. https://www.jcu.edu.au/state-of-the-tropics/publications/2014/2014-essaypdfs/Essay-1-Trewin.pdf. (accessed: 26 October 2017).

Tubiello, F.N., J. S. Amthor, K. J. Boote, et al. 2007. Crop response to elevated $\mathrm{CO}_{2}$ and world food supply: A comment on "Food for Thought." by Long et al., Science 312:19181921, 2006. Eur J Agron 26:215-23.

Uguru, M., K. Baiyeri, and S. Aba. 2011. Indicators of climate change in the derived savannah niche of Nsukka, south-eastern Nigeria. Agro-Science 10:17-26.

United Nations, 2014. Vietnam: Climate change threatens rice production. https://videos.un.org/en/2014/10/07/vietnam-climate-change-threatens-riceproduction-2/. (accessed: 26 October 2017). 
Usui, Y., H. Sakai, T. Tokida, H. Nakamura, H. Nakagawa, and T. Hasegawa. 2015. Rice grain yield and quality responses to free-air $\mathrm{CO} 2$ enrichment combined with soil and water warming. Global Change Biol 22:1256-70.

Van Valen, G. 2013. Indigenous Agency in the Amazon. Tucson: The University of Arizona Press.

Walker, G., and S. D. King, 2008. The hot topic: How to tackle global warming and still keep the lights on. London: Bloomsbury Publishing.

White, B. 1972. Supply projections for the Australian beef industry. Rev Mark Agric Econ 40:1-12.

Wilken, G. 1987. Good farmers: Traditional agricultural resource management in Mexico and Guatemala. Berkley: University of California Press.

Willcocks, J. and P. Young, 1991. Queensland's rainfall history: Graphs of rainfall averages: 1880-1988. CSIRO, Pasture Management Branch, Queensland Department of Primary Industries, Emerald, Australia.

Williams, J., and Jackson. 2007. Novel climates, no-analog communities, and ecological surprises. Front Ecol Environ 5:475-82.

Wollenberg, E., S. Higman, H. Seeberg-Elverfeldt, C. Neely, M. L. Tapio-Bistrom, and H. Neufeldt. 2012. Helping smallholder farmers mitigate climate change. CCAFS Policy Brief \#5. Copenhagen, Denmark.

World Bank, 2016. Vietnam: sustainable farming for higher productivity and a better environment. https://olc.worldbank.org/content/vietnam-sustainable-farming-higherproductivity-and-better-environment-0. (accessed: 26 October 2017).

Xie, L., Y. Li, and M. Lin. 2011. Response and adaptation to climate change of agriculture and environment in Northeast China. Chin J Eco Agric 19:197-201. 
Xue, F., P. Amilcare, and R. Ignacio. 2013. Changes in rainfall seasonality in the tropics. Nat Clim Change 3:811815. DOI: 10.1038/NCLIMATE1907.

Yates, D. N., and K. M. Strzepek. 1998. An assessment of integrated climate change impacts on the agricultural economy of Egypt. Climatic Change 38:261-87. 


\section{Table 1}

Global mean temperature increases projected for the 2090s compared to years 1986-2005 for 4 RCPs, according to CMIP5 results (Stocker at al. 2013)

\begin{tabular}{|c|c|}
\hline $\begin{array}{c}\text { Representative Concentration } \\
\text { Pathway }\end{array}$ & Temperature Increase \\
\hline RCP2.6 & $+{ }^{\circ} \mathrm{C}$ \\
\hline RCP4.5 & $+1.8 \mathrm{C}$ \\
\hline RCP6.0 & $+2.2^{\circ} \mathrm{C}$ \\
\hline RCP8.5 & $+3.7^{\circ} \mathrm{C}$ \\
\hline
\end{tabular}




\section{Table 2}

Summary of the risks to rice production experienced by smallholder farmers and the impacts of these risks on rice yields and household income (as reported by farmers). Numbers represent the per cent of farmers experiencing this problem or the means ( \pm SE). Redrawn from Chakraborty and Newton 2013.

\begin{tabular}{|c|c|c|c|c|c|c|c|c|c|c|c|}
\hline \multirow{2}{*}{$\begin{array}{l}\text { agricultural } \\
\text { risk }\end{array}$} & \multirow{2}{*}{$n$} & \multirow{2}{*}{$\begin{array}{c}\% \text { of } \\
\text { farmers } \\
\text { affected }\end{array}$} & \multirow{2}{*}{$\begin{array}{c}\text { frequency of risks } \\
\text { (mean number of } \\
\text { occurrences in last } 5 \\
\text { years) }\end{array}$} & \multicolumn{4}{|c|}{$\%$ of crop yields lost due to risks } & \multicolumn{4}{|c|}{$\begin{array}{c}\text { \% reduction in household income } \\
\text { due to risk }\end{array}$} \\
\hline & & & & $<25 \%$ & $25-50 \%$ & $50-75 \%$ & $>75 \%$ & $<25 \%$ & $25-50 \%$ & $50-75 \%$ & $>75 \%$ \\
\hline $\begin{array}{l}\text { significant } \\
\text { disease } \\
\text { outbreak }\end{array}$ & 539 & 47 & $1.6( \pm 0.08)$ & $56^{\mathbf{a}}$ & $29^{\mathbf{a}}$ & $15^{\mathrm{a}}$ & - & $10^{\mathbf{a}}$ & $32^{\mathbf{a}}$ & $41^{\mathrm{a}}$ & $15^{\mathrm{a}}$ \\
\hline $\begin{array}{l}\text { severe pest } \\
\text { damage }\end{array}$ & 539 & 81 & $3.1( \pm 0.09)$ & - & - & - & - & - & - & - & - \\
\hline $\begin{array}{l}\text { loss of crops } \\
\text { during storage }\end{array}$ & 539 & 36 & $1.3( \pm 0.09)$ & 88 & 10 & $2^{\mathbf{b}}$ & - & - & - & - & - \\
\hline cyclones & 524 & 51 & $1.2( \pm 0.1)$ & 30 & 29 & 30 & 26 & 39 & 30 & 21 & 10 \\
\hline $\begin{array}{l}\text { severe } \\
\text { flooding }\end{array}$ & 524 & 44 & $1.2( \pm 0.1)$ & 40 & 35 & 20 & 5 & 40 & 34 & 17 & 8 \\
\hline severe drought & 524 & 68 & $1.8( \pm 0.1)$ & 23 & 42 & 27 & 9 & 35 & 35 & 22 & 8 \\
\hline
\end{tabular}

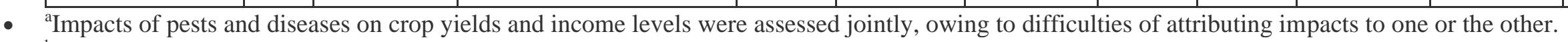

- ${ }^{\mathrm{b}}$ These numbers (for crop storage) refer to losses of more than $50 \%$. 


\section{Legends to Figures}

Figure 1. Distribution and variation in global tropical climates. Savannah lands have distinct wet-dry cycles and can be subject to drought conditions, whereas Monsoon and Rainforest tropics may get wetter and rain, more sporadic, with climate change.

Figure 2. Hierarchical framework depicting the interaction between the farming and production systems in the tropics.

Figure 3. Different tropical crop production systems are more resilient than others, whereas conversely, production systems also show different vulnerabilities to a changing climate. 
Figure 1

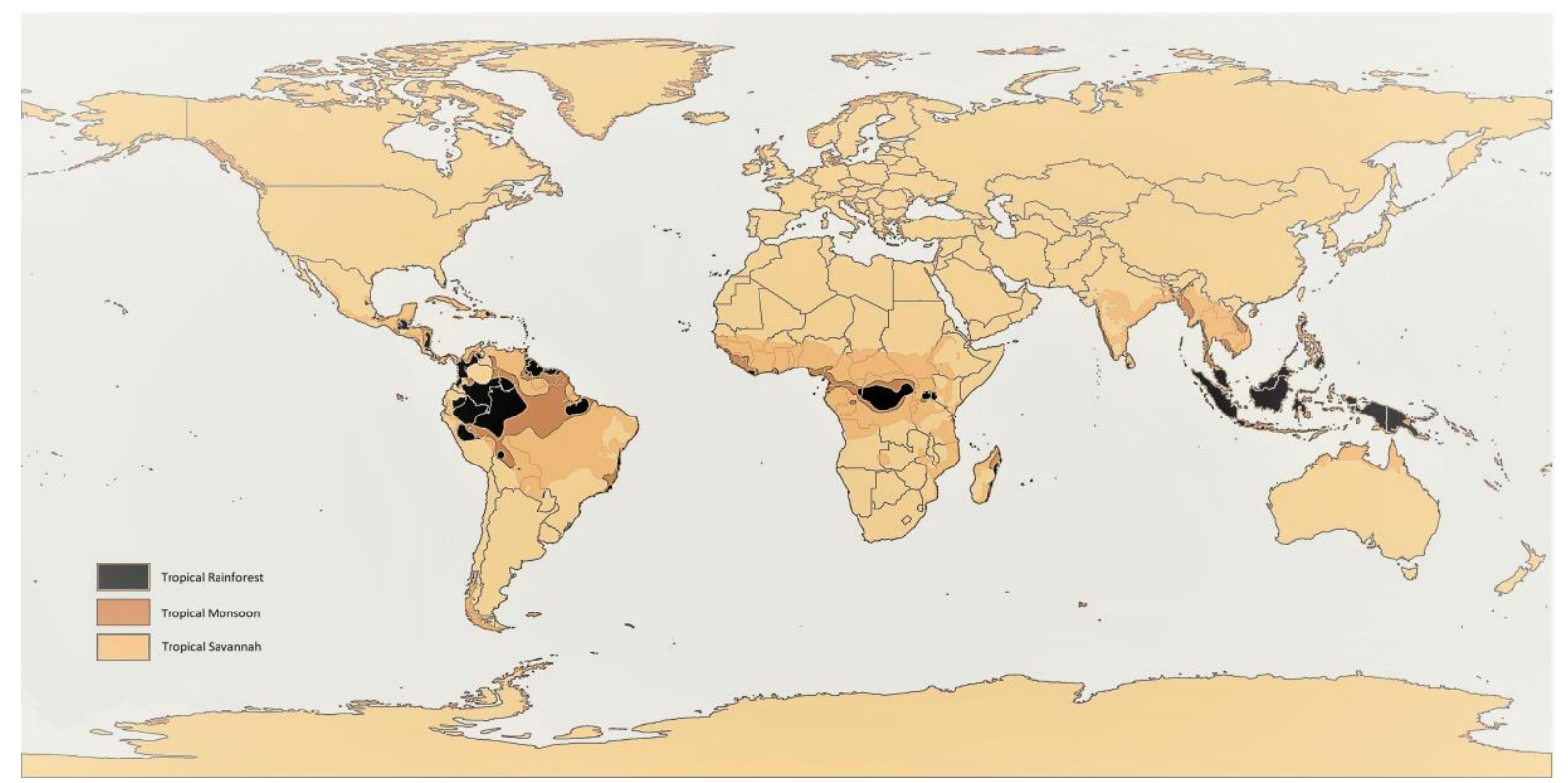




\section{Figure 2}

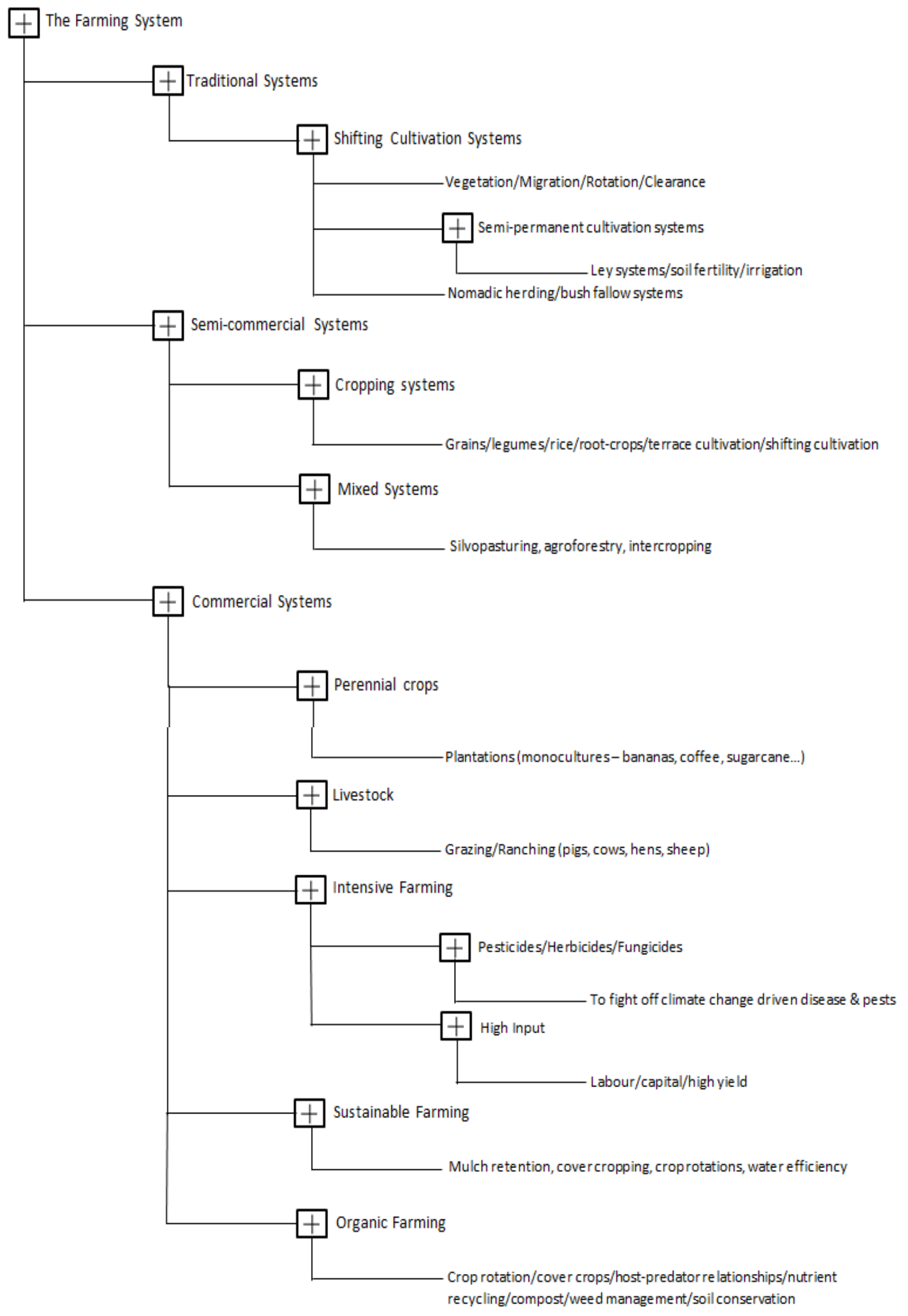


Figure 3

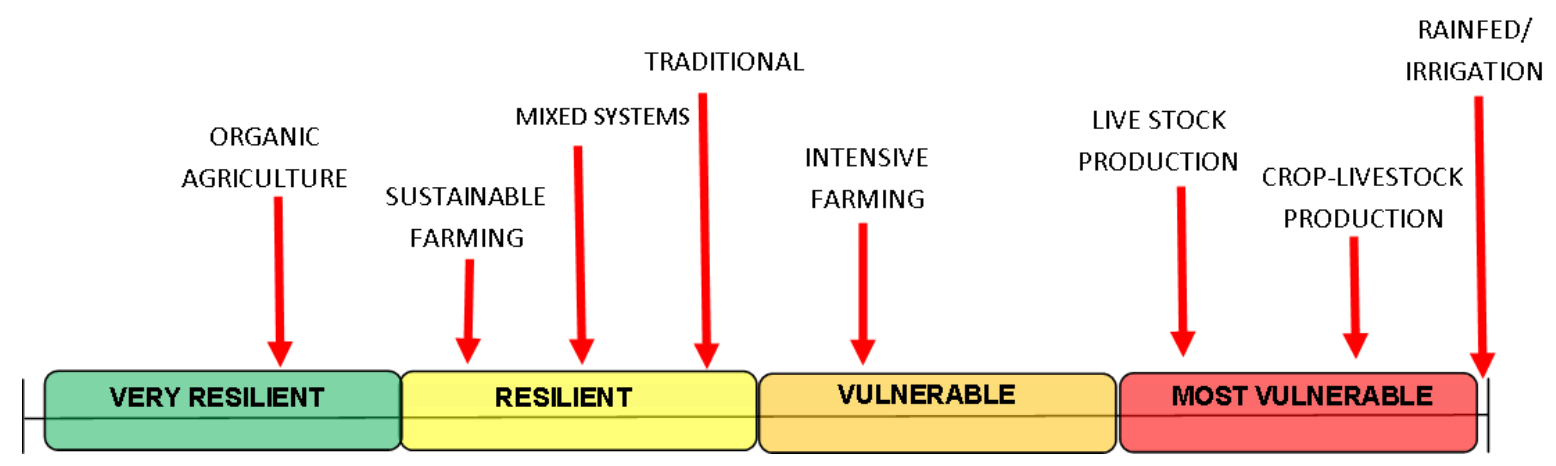

